\title{
Tidally dominated sediment dispersal offshore of a small mountainous river:
}

\section{Elwha River, Washington State}

\author{
E.F. Eidam ${ }^{\mathrm{a},{ }^{*}}$, A.S. Ogston ${ }^{\mathrm{a}}$, C.A. Nittrouer ${ }^{\mathrm{a}}$, J.A. Warrick ${ }^{\mathrm{b}}$ \\ ${ }^{\text {a } U n i v e r s i t y ~ o f ~ W a s h i n g t o n, ~ S c h o o l ~ o f ~ O c e a n o g r a p h y, ~ B o x ~ 357940, ~ S e a t t l e, ~ W A ~ 98103, ~ U n i t e d ~ S t a t e s ~}$ \\ ${ }^{\mathrm{b}}$ U.S. Geological Survey, 400 Natural Bridges Drive, Santa Cruz, CA 95060, USA
}

\section{Abstract}

Sediment supplied by small mountainous rivers (SMRs) represents a major fraction of the global ocean sediment budget. Studies from the past two decades have shown that much of this sediment is dispersed by episodic wind and wave energy along storm-dominated coasts. In tidally dominated environments, however, different transport styles and deposits may result from persistent tidal dispersal. This study investigates episodic sediment releases generated by dam removal from a SMR in Washington State, in order to evaluate the mechanics of tidally dominated sediment dispersal in an energetic marine environment. The results indicate that asymmetric tidal currents with peak magnitudes of $\sim 50$ to $>80 \mathrm{~cm} / \mathrm{s}$ produce daily sediment export in the direction of the dominant tidal phase (i.e., the semi-diurnal phase with faster currents and longer duration), resulting in dispersal of fluvially derived fine sediment to distal sinks. These effects are observed throughout all seasons in the presence or absence of wave events. During the first two years of dam removal, more than 8 million tonnes of sediment were discharged to the coast. The net result was little to no change in grain size at 10-60 m water depth across $>70 \%$ of the seabed offshore of the river mouth. Over the remaining $\sim 2-3 \mathrm{~km}^{2}$ of the subaqueous delta, several $\mathrm{cm}$ of mud and sand accumulated in a sheltered coastal embayment adjacent to the river mouth. These results demonstrate that SMR discharge events may form patchy, isolated deposits—or even no deposits—along coastlines with strong tidal currents, in contrast to the mid-shelf mud belts formed on storm-dominated shelves. Over longer timescales, knowledge of the erosional capacity of local and regional tidal currents may be key to interpreting the terrestrial event record preserved in (or possibly excluded from) marine SMR deposits.

Keywords: Elwha River; sediment dispersal; tidal system; dam removal; flood deposit

* Corresponding author. Tel: +1 206543 8544. UW School of Oceanography, Box 357940, Seattle, WA 98195. E-mail addresses: efe@uw.edu (E.F. Eidam), ogston@ocean.washington.edu (A.S. Ogston), nittroue@ocean.washington.edu (C.A. Nittrouer), jwarrick@usgs.gov (J.A. Warrick). 


\section{Introduction}

Small mountainous rivers (SMRs) are a key source of sediment to the coastal ocean, especially along tectonically active continental margins (Milliman and Syvitski, 1992). Because they drain small basins, these rivers often deliver much of their annual sediment load in conjunction with discrete events such as floods, forest fires, landslides, or earthquakes. Recently, SMRs have been the focus of studies investigating the sediment transport effects of "wet" storms that bring brief periods of simultaneous/coherent precipitation and energetic ocean conditions to mountainous coastlines (e.g., Wheatcroft, 2000; Sommerfield et al., 2007; Fain et al., 2007; Bourrin et al., 2008; Drexler and Nittrouer, 2008; Harris et al., 2008; Ulses et al., 2008; Kniskern et al., 2011; Bever et al., 2011; Grifoll et al., 2014). The common result is rapid sediment delivery from rivers and efficient transport of that sediment through the shallow marine environment, leading to broad dispersal and deposition in continental-margin flood deposits.

In contrast to these storm-dominated systems, some SMRs discharge to tidally dominated environments where sediment delivery is episodic, but transport energy is periodic_-and in some cases sufficient to mobilize the majority of supplied particle sizes each day. Tidally dominated systems account for $\sim 17 \%$ of the world’s continental shelves (Walker, 1984; Swift et al., 1986), and include macrotidal and mesotidal embayments/estuaries and also tidal straits (Reading, 2009). In order to better understand the timing, variability, and depositional impacts of tidally dominated transport in these environments, the present study investigates sediment pathways and deposits offshore of a SMR during a dam deconstruction/river restoration project. The dam removal project, which involved two 100-year-old hydroelectric dams on the Elwha River in Washington State, released $\sim 8.2$ million tonnes of total sediment including $\sim 6.3$ million tonnes of suspended sediment to the coastal ocean between Sep 2011 and Sep 2013 (Magirl et al., 2015; 
Warrick et al., 2015). Episodic fluvial sediment pulses with a range of magnitudes were generated, offering the opportunity to investigate the dispersal of sediment from SMR delivery events.

Data collected from boundary-layer instruments near the river mouth and from shipbased surveys across the delta were used to: (1) characterize the transfer of material from the buoyant surface plume into the underlying water column; (2) describe tidally dominated patterns of sediment resuspension, advection, and settling in the water column and bottom boundary layer; and (3) understand the location of new seabed deposits and predict their evolution. The results of this study expand our understanding of tidally driven dispersal systems and their deposits offshore of SMRs.

\section{Regional characteristics}

\subsection{Physical characteristics of the river and receiving basin}

The Elwha River flows $72 \mathrm{~km}$ from the tectonically active Olympic Mountains to the Strait of Juan de Fuca in northwest Washington State (Fig. 1). Like many SMRs, the Elwha has a steep gradient, large sediment discharge relative to river size $\left(1.2-2.9 \times 10^{5} \mathrm{~m}^{3} / \mathrm{yr}\right.$ upstream of the former reservoirs; Curran et al., 2009), and small drainage basin (827 km²; Konrad, 2009), and therefore a large sediment yield. The basin receives $100-500 \mathrm{~cm}$ of precipitation in the form of rain and snow each year (Phillips and Donaldson, 1972) and the river hydrograph is characterized by a mean annual flow of $42.8 \mathrm{~m}^{3} / \mathrm{s}$ at USGS site 12045500 (Curran et al., 2009; USGS, 2015) with peaks reaching 200-300 m³/s during autumn/winter storms and spring freshets/snowmelt periods (USGS, 2015).

The river discharges into the Strait of Juan de Fuca, a roughly 20-km wide, 100-km long east-west channel connecting the Pacific Ocean to inland seas (Fig. 1). The subaerial river delta 
extends $\sim 2 \mathrm{~km}$ into the Strait of Juan de Fuca, and a relict, subaqueous delta (henceforth referred to as the “delta”) extends an additional $2-5 \mathrm{~km}$. This platform dips $\sim 1^{\circ}$ toward a slope break at 40-60 m depth; the adjacent channel floor is 120 m deep. The delta began forming about 12,500 years ago during a high stand in sea level after the Vashon Glaciation (Anderson, 1968; Downing, 1983; Webster, 2014). As the earth’s crust rebounded, sea level fell to $60 \mathrm{~m}$ below the modern shoreline (Mosher and Hewitt, 2004), and the delta prograded into the Strait. Finally, eustatic sea level rose to its present level 5000 years ago and flooded the lowstand delta (Downing, 1983; Webster, 2014), which is the study area for this work.

The delta lies in the Elwha littoral cell between Freshwater Bay and Ediz Hook (Fig. 1). Freshwater Bay is a sheltered region that receives sediment from both the river and eroding glacial bluffs (Shaffer, 2008). Ediz Hook is an active spit formed from eastward longshore transport of river and bluff sediments (Galster and Schwartz, 1990). Prior to the release of sediment from the reservoirs, the substrate across the relict, subaqueous delta was a mixture of sands, gravels, and irregularly distributed boulders, with the finest sediments (typically sands) found in Freshwater Bay (Warrick et al., 2008; Webster, 2014). The coarser gravelly and sandy substrate on the remainder of the delta has been interpreted as a lag layer (Webster, 2014). Little data are available on subaqueous delta sediments prior to dam construction, except for reports of sandy deposits in intertidal zones (Lower Elwha Klallam Tribe; Reavey, 2007 in Warrick et al., 2009) and shallow waters (to 18 m depth) near the mouth (Rigg, 1913, 1915).

During the first two years of the dam removal/restoration project, $\sim 8.2$ million tonnes of sediment—including 6.3 million tonnes of suspended load (sand, silt, and clay) — were delivered to the coastline (Magirl et al., 2015; Warrick et al., 2015). Approximately 3.5 million tonnes of this sediment accumulated at the river mouth or in nearby seabed deposits; most of this 
sediment was sand and gravel deposited at water depths $\leq 8 \mathrm{~m}$. The remaining $\sim 5$ million tonnes, comprised primarily of fine-grained sediment, is thought to have been broadly dispersed (Gelfenbaum et al., 2015).

\subsection{Regional and local hydrodynamics}

Local hydrodynamics are affected by tidal currents and estuarine circulation in the Strait, surface gravity waves, wind-driven circulation, and complex coastal morphology. Tides in the Strait are mixed, semi-diurnal with spring ranges of 3-4 m (Holbrook et al., 1980). Basin-scale circulation follows an estuarine pattern with mean seaward flow of $\sim 20-50 \mathrm{~cm} / \mathrm{s}$ in the upper water column and mean landward flow of $\sim 10 \mathrm{~cm} / \mathrm{s}$ in the lower water column (e.g., Cannon, 1978; Labrecque et al., 1994; Thomson et al., 2007). Tidal currents $>100 \mathrm{~cm} / \mathrm{s}$ have been recorded in the central part of the Strait (e.g., Fissel and Huggett, 1976; Sternberg, 1968). The wave climate is dominated by Pacific Ocean swell and wind-driven waves from the west and northwest (Warrick et al., 2009; Downing, 1983) with wave heights typically 0.5 to $\sim 1 \mathrm{~m}$, and occasionally $>2$ m (Warrick et al., 2009).

Local ebb and flood tidal currents are asymmetric, i.e., unequal in magnitude and duration. Numerical models predict flow separation around the delta headland (Fig. 1), leading to the formation of eddies both east and west of the river mouth (Gelfenbaum et al., 2009; Gelfenbaum et al., 2015). During flood tides, a clockwise eddy forms over the eastern delta, and during ebb tides, a weaker counterclockwise eddy forms in Freshwater Bay. The net effect of these eddies is residual current flow north/northeastward from the river mouth at $16-17 \mathrm{~cm} / \mathrm{s}$ (Warrick and Stevens, 2011; Gelfenbaum et al., 2015), and a minima in current speed in Freshwater Bay. These flow patterns have the potential to affect the buoyant sediment plume (Warrick and Stevens, 2011) as well as boundary-layer transport. 
Hydrodynamics on the subaqueous delta are generally unfavorable for fine-grained sediment deposition (Warrick and Stevens, 2011; Webster, 2014). Studies from 2008, prior to release of reservoir sediments from dam removal, showed surface-plume concentrations up to $0.070 \mathrm{~g} / \mathrm{L}$ near the river mouth, and maximum boundary-layer suspended-sediment concentrations (SSC) of 0.002-0.010 g/L at $100 \mathrm{~cm}$ above bed (cmab) (Webster, 2014). Surface waves and tidal currents, which produce shear velocities capable of moving sand-size particles, have been proposed as mechanisms whereby the delta substrate has been winnowed of fine sediments (Warrick et al., 2008; Webster, 2014). This study investigates the hydrodynamics of water-column and boundary-layer transport in detail near the river mouth, and compares these dynamical observations to seabed textures across the delta in order to better understand tidal dispersal of SMR sediment to proximal and distal sinks. The dam-removal period affords a special opportunity to study these effects over a range of fluvial inputs in a discrete time frame.

\section{Methods}

\subsection{Time-series data}

Discharge and SSC data for the Elwha River are reported from calibrated U.S. Geological Survey (USGS) turbidity and water-level sensors located $5.6 \mathrm{~km}$ upstream of the mouth at USGS station 12046260 (Curran et al., 2014). Gauged bedload data for year 2 of dam removal are reported from the same site (Magirl et al., 2015).

An instrumented bottom-boundary-layer (BBL) tripod, similar to those described by Ogston et al. (2000, 2008), was deployed 250-500 m northwest of the Elwha River mouth (Fig. 1) in 14-17 m of water from Nov 2011 to Aug 2013. A second tripod with fewer sensors was deployed 600-800 m northwest of the river mouth in 17-28 m of water during Apr to Jun 2012 and Oct 2012 to Aug 2013, and provided additional measurements during the spring freshet and 
winter storms. Both tripods were outfitted with acoustic and optical sensors (Table 1) designed to measure suspended-sediment concentrations (SSC) and water-column properties in the lowest 2 m of the water column, as well as currents throughout the entire water column. Sediment tube traps $6.6 \mathrm{~cm}$ in diameter were mounted with openings at $\sim 111 \mathrm{cmab}$ to collect suspended sediment.

Anti-fouling coatings or collars were applied to optical sensors and conductivity sensors. The conductivity data appeared unaltered by biofouling, but some data were omitted because the sensor intake was periodically clogged by sediment. Optical-backscatter-sensor (OBS) data affected by biofouling (typically the last few weeks of long deployments) were also omitted, and gradual downward drifts in the data (where present) were corrected to the mean low value from the first part of the deployment. Each OBS was calibrated during tripod servicing by measuring the backscatter response to varying concentrations of tube-trap sediment mixed with seawater. A linear regression was applied to the data points to obtain a calibration equation (after Downing, 2006).

Acoustic backscatter data were converted from raw echo counts to $\mathrm{dB}$ according to the relationship given by Deines (1999). This method corrects for power attenuation due to beam spreading and sound absorption by water. These data were used as a qualitative proxy for suspended-sediment concentrations throughout the water column.

Combined wave-current shear velocities $\left(u_{* c w}\right)$ were estimated using the Madsen model (Madsen, 1994). Wave-orbital velocities were obtained between frequencies of 1/5 and 1/20 Hz; the angle between waves and currents was conservatively assumed to be $90^{\circ}$ (to minimize $u_{* c w}$ estimates); and the assumed Nikuradse roughness $\left(k_{s}\right)$ was $0.0025 \mathrm{~m}$. This roughness value was 
computed using a nominal grain diameter of $1 \mathrm{~mm}$ and the following relationship for sandy beds (e.g., Soulsby, 1997):

$$
k_{s}=2.5 d_{50}
$$

A sensitivity test of $u_{* c w}$ was performed for $k_{s}$ values of $0.001 \mathrm{~m}, 0.0025 \mathrm{~m}$, and $0.01 \mathrm{~m}$. The resulting mean $u_{* c w}$ values over the time series were $1.37 \mathrm{~cm} / \mathrm{s}, 1.55 \mathrm{~cm} / \mathrm{s}$, and $1.91 \mathrm{~cm} / \mathrm{s}$, respectively. All of these values exceeded the $0.9 \mathrm{~cm} / \mathrm{s}$ threshold of motion for sand (published by Miller et al., 1977; modified from Inman, 1949), and although the $u_{* c w}$ magnitudes varied with $k_{s}$, the patterns of $u_{* c w}$ relative to tidal phase did not change with the choice of $k_{s}$. Mean settling velocities $\left(w_{s}\right)$ of the suspended particle/aggregate population were estimated from 8-Hz ADV data collected in autumn/winter 2012 using the Reynolds flux method described by Fugate and Friedrichs (2002) (see also Cartwright et al., 2013). Estimates coinciding with mean currents $<15 \mathrm{~cm} / \mathrm{s}$ or OBS concentrations $<0.020 \mathrm{~g} / \mathrm{L}$ were omitted to reduce errors related to unsteady flow and non-settling washload (after Cartwright et al., 2013); per these criteria, $w_{s}$ estimates were obtained from $\sim 50 \%$ of measurements.

\subsection{Spatial data collection from ship-based surveys}

Surface water samples, CTD profiles, and seabed grab samples were obtained from the R/V Barnes and R/V Centennial at 30-80 stations across the subaqueous delta (Fig. 1) during surveys in Nov 2011; Apr, Jun, and Oct 2012; and Jan, Apr, and Aug 2013. Some surveys included limited seabed video observations for qualitative textural information. Additional seabed and water samples were collected near the river mouth from small boats in Apr 2012, Nov 2012, and Apr 2013.

Surface-water samples and CTD profiles were gathered inside and outside the surface plume. Water samples were collected using a Niskin sampler, and were filtered in the lab 
through $0.45-\mu \mathrm{m}$ nitrocellulose filters. Temperature, salinity, and SSC profiles were measured from $10-50 \mathrm{~cm}$ below the surface to $10 \mathrm{cmab}$ using a small, robust CTD with integrated OBS. Transects both parallel and perpendicular to shore were completed within 1-4 hr to minimize effects of changing tides. OBS measurements were converted to $\mathrm{g} / \mathrm{L}$ using filtered surface-water samples collected in conjunction with CTD/OBS casts.

Seabed sediment samples were obtained with a Shipek grab sampler. Failed grabs were attributed to gravel, cobbles, and/or boulders, consistent with observations in Webster (2014) and video footage collected in this study showing coarse substrates. Sediment samples were analyzed in the lab as follows: mud ( $<63 \mu \mathrm{m}, 4 \varphi$ ) was separated from coarser sizes by wet-sieving in a solution of $0.05 \%$ sodium metaphosphate; sand and gravel were dried and sieved; and mud was processed using a Micromeritics Sedigraph. Samples containing gravel whose total dry weight was $<50$ g were omitted from further analyses because the sample size was considered insufficient for an accurate estimation of grain-size distribution. Finally, samples were categorized into seven types based on a simplified version of the ternary classification presented by Folk (1954).

\section{Results}

\subsection{River load and surface plume}

Consistent with historical patterns, the Elwha River hydrograph peaked during autumn/winter rainstorms and the spring freshet (Fig. 2a). Typical rainstorms produced river flows of $70-220 \mathrm{~m}^{3} / \mathrm{s}$, while the spring freshets produced flows of $80-190 \mathrm{~m}^{3} / \mathrm{s}$. The peak flow during the study period was $290 \mathrm{~m}^{3} / \mathrm{s}\left(10,300 \mathrm{ft}^{3} / \mathrm{s}\right)$ on 27 Nov 2011. The river did not reach flood stage during this time (i.e., a gauge height $>20.0 \mathrm{ft}$ at USGS station 12045500 , nwis.waterdata.usgs.gov). River SSC generally increased throughout the study period (Fig. 2a), 
and increased dramatically in response to rainstorms, the spring freshet, and dam deconstruction activities. During several discharge events, maximum river SSC exceeded the range of the turbidity sensor, representing a mass concentration >5.7 g/L (Magirl et al., 2015).

Increases in fluvial SSC coincided with increases in surface plume SSC, which was consistently low ( 0.010 g/L) during summer low-flow periods (Oct 2012 and Aug 2013). However, plume SSC increased 1-2 orders of magnitude during high-flow periods; for example, $0.075 \mathrm{~g} / \mathrm{L}$ in Nov 2011 and $1.6 \mathrm{~g} / \mathrm{L}$ in Apr 2013 at similar river discharges. The maximum plume SSC of $2.5 \mathrm{~g} / \mathrm{L}$ for the entire study was observed in Nov 2012 during a rainstorm, when field samples at USGS station 12045500 showed river SSC >11 g/L (USGS, 2015). During all surveys, the surface plume was consistently 1-3 m thick and the area with SSC greater than $0.005 \mathrm{~g} / \mathrm{L}$ was limited to a zone within $3 \mathrm{~km}$ of the river mouth (data not shown).

\subsection{Tidal currents, waves, and bottom stresses}

At the primary tripod site, tidal currents measured $50 \mathrm{cmab}$ ranged from 0 to $\sim 50 \mathrm{~cm} / \mathrm{s}$ during neap phases and from 0 to $\sim 80 \mathrm{~cm} / \mathrm{s}$ during spring phases (Fig. 2e). Maximum spring tidal currents of $\sim 100 \mathrm{~cm} / \mathrm{s}$ were observed in mid-May, early Jun, mid-Dec, and mid-Jan, coincident with the summer and winter solstices.

Currents were asymmetric in magnitude and duration. At the primary tripod site (depth 14-17 m), currents were generally directed northeastward during flood tides and southwestward during ebb tides. Over the 20-month study period, currents flowed northeastward (10-60) 64\% of the time with average magnitude of $33 \mathrm{~cm} / \mathrm{s}$ and standard deviation of $18 \mathrm{~cm} / \mathrm{s}$. The currents flowed southwestward (200-250 $) 15 \%$ of the time with average magnitude of $15 \mathrm{~cm} / \mathrm{s}$ and standard deviation of $7 \mathrm{~cm} / \mathrm{s}$. At the deeper, secondary tripod site (depth 17-28 m), currents were of similar magnitude and direction (not shown). 
Significant wave heights at the primary tripod site (Fig. 2d) averaged $0.49 \mathrm{~m}$ (median $0.45 \mathrm{~m}$; maximum $2.43 \mathrm{~m}$ ). The range of wave-orbital velocities was $1-40 \mathrm{~cm} / \mathrm{s}$; values were $<20 \mathrm{~cm} / \mathrm{s}$ in $97 \%$ of measurements.

Combined wave-current boundary-layer shear velocities $\left(u_{* c w}\right)$ at the primary tripod site were $0-5.0 \mathrm{~cm} / \mathrm{s}$ (Fig. 2f). Large shear velocities coincided with large current velocities. Shear velocities exceeded $\sim 0.9 \mathrm{~cm} / \mathrm{s}$, the threshold of motion for very fine sand, $\sim 80 \%$ of the time; the threshold of motion for very coarse sand, $\sim 2.3 \mathrm{~cm} / \mathrm{s}$, was exceeded $\sim 16 \%$ of the time. Note that when $k_{s}=0.0001 \mathrm{~m}$ is used to estimate a more conservative $u_{* c w}$, these thresholds are exceeded in $53 \%$ and $4 \%$ of measurements, respectively, though the pattern of peak $u_{* c w}$ coincident with flood tide remains the same.

A rough classification of hydrologic seasons was defined by periods of time when mean, daily long-term discharge was approximately greater or less than the cumulative 1897-2013 mean value of $\sim 43 \mathrm{~m}^{3} / \mathrm{s}$. Using this definition, two high-flow seasons (winter, Nov-Feb; freshet, May-Jul) and two low-flow seasons (summer, Jul-Oct; late winter, Mar-Apr) were defined. During these hydrologic seasons, little variability was observed in tidal currents, wave-orbital velocities, and $u_{* c w}$ for calendar year 2012 (Fig. 3b) (note that 2012 included data gaps for maintenance shown in Fig. 2). In all seasons, most $u_{* c w}$ values exceeded the threshold of motion for sand, and the distribution of values generally followed the distribution of current speeds (Fig. 3b).

\subsection{Suspended-sediment dynamics}

Peaks in boundary-layer SSC generally coincided with fluvial delivery events (Fig. 2a, g), and were greatest in autumn/winter 2012 when the Lake Mills delta prograded to the site of Glines Canyon Dam (Warrick et al., 2015). At the primary tripod site, maximum SSC at $50 \mathrm{cmab}$ 
increased from $0.035 \mathrm{~g} / \mathrm{L}$ (autumn/winter 2011) to $0.22 \mathrm{~g} / \mathrm{L}$ (2012 spring freshet), and then to $0.76 \mathrm{~g} / \mathrm{L}$ (autumn/winter 2012). Net BBL sediment flux was directed northeastward during all seasons, and the cumulative sediment flux magnitude followed that of the river (Fig. 2b, g).

Boundary-layer SSC generally increased within hours of fluvial-discharge events, and remained high for days to weeks after fluvial discharge subsided, as illustrated by a typical series of winter events in Fig. 4. During both small and large events (see early and late Nov 2012), boundary-layer SSC fluctuated with tidal currents, though the magnitude of SSC depended on the quantity of sediment discharged by the river. Wave resuspension events were rare; the most notable event occurred in mid-Nov 2012 (Fig. 4).

On daily time scales, SSC in both the water column and boundary layer fluctuated in conjunction with plume delivery and tidal currents. Vertical suspended-sediment concentration gradients formed throughout the water column during both spring and neap tides (Fig. 5a, b), as seen in the corrected upward-looking ADCP backscatter intensity. In the boundary layer, spring and neap tides caused distinct patterns of SSC. During spring tides, maximum SSC values occurred during the onset of the strong flood, maximum flood currents, and the slack period between flood and ebb. The SSC peaks during maximum flood currents coincided with maximum $u_{* c w}$ and $w_{s}$ values. During neap tides, SSC peaks were associated with the onset of flood currents and slack periods, and did not coincide with maximum $u_{* c w}$ and $w_{s}$ values.

\subsection{Grain-size distributions at instrument sites and across the delta}

Grain-size distributions of suspended sediment captured in the tube traps offshore of the river mouth were characterized by 5-25\% sand (1-4 $\varphi$ ), 65-75\% silt (5-8 $\varphi$ ), and 10-25\% clay (finer than 8 甲) (Fig. 6). From Nov 2011 to Aug 2013, grain-size distributions at both tripod sites were similar, and varied little between deployments (Fig. 6). 
Seafloor grain-size distributions changed over the course of the study in some, but not all, portions of the relict delta and Freshwater Bay (Fig. 7a). Early in the study (Nov 2011/Apr 2012), the finest sediment (mostly sand) was found in Freshwater Bay, west of the river mouth. The coarsest substrate (generally gravel) was found north and northeast of the river mouth. Sampling over the east portion of the delta commonly failed to recover any sediment (Fig. 7), and seabed videos collected in Nov 2011 and Apr 2013 showed boulders and gravel at many sample sites.

By Apr and Aug 2013, new sand and mud were found in Freshwater Bay (Fig. 7b). In Aug 2013, this new deposit extended $\sim 1.2 \mathrm{~km}$ offshore to $\sim 20 \mathrm{~m}$ water depth. Surficial grain sizes coarsened away from the river mouth both westward and northward. At shallow depths of 10-13 m, mud fractions were 80-95\%; outside the new deposit beyond 20 m depth, mud fractions were $\sim 10 \%$. All other regions of the submarine delta (i.e., near the river mouth, north of Freshwater Bay, and north/northeast of the delta headland) retained their coarse composition of mixed sands, gravels, and boulders with minor amounts of mud, similar to the Nov 2011 survey.

\section{Discussion}

Offshore of the Elwha River mouth (in depths $\geq 10 \mathrm{~m}$ ), tidal currents dominate the export of fine-grained, fluvial sediment. This dispersal style, which contrasts with well studied, opencoast, storm-dominated systems (e.g., Wright et al., 1999; Wheatcroft, 2000; Kniskern et al., 2011; Bever et al., 2011), is a product of strong tidal-current magnitudes, tidal-current asymmetry, and relatively weak wave energy. Here we address these mechanics on time scales of semi-diurnal tides, fortnightly tidal phases, fluvial delivery events, and seasonal variability to explain the partitioning of sediment in the Elwha system and within tidally dominated dispersal systems generally. 
The Elwha system offers a good example of tidally dominated sediment dispersal: during the study period, $~ 6.3$ million tonnes of suspended sand, silt, and clay were delivered by the river owing to dam removal (Magirl et al., 2015). This sediment was delivered over various seasons and tidal phases, thus providing sediment loading analogous to delivery events like floods and landslides seen in other environments. The following sections discuss the general patterns of sediment dispersal in the plume, water column, and boundary layer.

It is worth noting that during the study, the thickness and nearfield extent of the plume changed little relative to baseline studies (see Warrick and Stevens, 2011), despite SSC increases of up to two orders of magnitude. This means that the location of sediment transfer from the surface plume the water column was relatively consistent during the study when averaged over a tidal cycle, allowing for reasonable comparisons of dispersal processes at a single, fixed site offshore of the river mouth (Fig. 1).

\subsection{Broad dispersal of sediment in the upper water column}

In the plume and water column, fine-grained particles are subject to advection by tidal currents on semidiurnal time scales, and some of this sediment may be exported from the study area before reaching the boundary layer. Consider, for example, silt particles of 4-63 $\mu \mathrm{m}$ diameter. According to Stokes’ Law, unflocculated particles of this size would require at least 2 hr to settle $20 \mathrm{~m}$. Similarly, flocs would require $\sim 6 \mathrm{hr}$ to settle if we assume a nominal settling velocity of $1 \mathrm{~mm} / \mathrm{s}$ per Hill et al. (2000). In contrast, sand would settle $20 \mathrm{~m}$ in less than $2 \mathrm{hr}$, and likely enter the shallow longshore transport zone. Given these characteristic timescales of settling and known tidal excursions of up to $10 \mathrm{~km}$ (Warrick and Stevens, 2011), some silts and flocculated particles likely bypass the 2-5-km wide delta entirely before reaching the seabed. Beyond the delta, estuarine circulation in the Strait (westward near the surface and eastward near 
the bed; Cannon, 1978) likely carries this sediment eastward and/or westward to deep, distal basins. Once lost from the relict delta, this sediment would be unavailable to nourish coastlines or form concentrated flood deposits. Backscatter and velocity data from the ADCP (Fig. 5) show horizontal advection of particles throughout the water column, consistent with export of sediment away from the river mouth as it settles toward the bed.

\subsection{Semi-diurnal boundary-layer dispersal during both spring and neap tides}

While some sediment is likely advected beyond the study area before reaching the bed, the remainder enters a complex, boundary-layer transport zone where sediment flux is dominated by daily tidal cycles (discussed here) and fluvial events (discussed in section 5.3). Typical spring and neap tidal phases both produce net, northeastward transport; the mechanics are described below and illustrated in Fig. 5.

At the initiation of strong flooding currents (Fig. 5a, period marked A), mud and fine sand can be locally resuspended and transported northeastward, generating a peak in SSC at the measurement site, and the plume hugs the coast east of the mouth (Fig. 8a). After the initial cloud of fine particles is dispersed northeastward, a secondary pulse of larger particles arrives in conjunction with peak bed stresses, indicating resuspension and transport near the bed (Fig. 5a, period B). This delayed, secondary signal likely represents a scour lag common to tidal environments (e.g., Postma, 1961; Dyer, 1994); in other words, coarser particles travel near the bed at speeds slower than the mean flow, thus producing a lag between peak currents and peak SSC. But because strong flooding currents persist for several hours, both small and large particles are exported northeastward. The $w_{s}$ data (Fig. 5) and sediment-trap data (Fig. 6) confirm that particles ranging from clay to medium sand—or larger—are in transport, and the SSC data (Fig. 5a, period B) demonstrate that the supply of movable sediment is exhausted $\sim 11 \mathrm{hr}$ after the 
start of the flooding phase. This highlights the competency of currents in this system to export sediment away from potential depocenters (i.e., Freshwater Bay) because of both strong current magnitudes and a prolonged flooding phase associated with the local tidal asymmetry.

During ebbing currents, the plume migrates westward, and delivers sediment directly to Freshwater Bay (Fig. 5a, period C; Fig. 8a). Some boundary-layer sediment is also resuspended and imported into the bay, though the resuspension capacity is small because of the relatively weak ebb currents (Fig. 5a, period C). At the end of the ebb phase, a settling lag signal appears wherein the peak SSC occurs after the minima in current speed (Postma, 1961; Dyer, 1994), suggesting that some of the fine sediment that arrives during the ebb phase is re-exported by the flood tide before it settles to the bed. Nevertheless, transport during this phase is, in general, an important mechanism for deposit formation, because currents in the bay are weaker than currents elsewhere on the relict delta, particularly during ebb tides (see Gelfenbaum et al., 2009). Some sediment that arrives via the plume and boundary layer may be re-exported during the next flood tide, but the remainder forms the deposit described in section 4.5.

During neap tides, similar patterns of flood and ebb resuspension and advection occur, but there is more potential to retain sediment in Freshwater Bay. Current speeds, $u_{* c w}$, and $w_{s}$ are all reduced during neap flood tides (Fig. 5b; Fig. 8b). This means less coarse sediment—and less total sediment—is advected out of Freshwater Bay, as evidenced by the single rather than double peak in SSC during the flood tide.

In summary, during both spring and neap phases, fine-grained sediment is broadly dispersed in a net, northeastward direction because of tidal asymmetry. Sediment settling from the plume is advected toward the Strait during flood tides and toward Freshwater Bay during ebb tides (Fig. 8). Because the flood tidal currents are stronger and longer in duration, and because 
the plume is more often diverted eastward than westward (Warrick and Stevens, 2011), much of the sediment settling from the plume is likely advected toward the Strait. In the boundary layer, sediment as large as sand is advected northeastward from local sites and possibly from Freshwater Bay, particularly during spring tides when flood tide currents are greatest (Fig. 8a). During ebb tides, brief, weak currents carry some but not all of this material back to Freshwater Bay, where it can temporarily settle and accumulate. Northeastward export is most pronounced during spring tides, when there is a greater contrast between flood and ebb current magnitudes (Fig. 8a). During neap tides, the flood/ebb inequality and thus export from Freshwater Bay is muted, allowing more sediment to remain in the nearshore deposit (Fig. 8b).

\subsection{Event-scale sediment dispersal, and the role of waves}

Because tidal currents provide nearly continuous transport conditions, fine-grained sediment pulses from fluvial events are quickly and efficiently dispersed in the BBL. For example, SSC increased within hours of the start of a fluvial delivery event in Nov-Dec 2012 (Fig. 4), and remained high in the BBL until about a week after fluvial discharge abated. Suspended-sediment concentrations fluctuated on tidal time periods, and decreased to background levels once the supply of movable material was exhausted. This pattern is typical of fluvial events during the study (Fig. 2) and contrasts with storm-dominated systems, where: SSC fluctuates in concert with waves rather than tidal currents (e.g., Eel River/shelf; Ogston and Sternberg, 1999); storm energy may subside before the supply of "fresh" material is exhausted (Eel River/shelf; Wheatcroft, 2000); storm direction may enhance shallow deposition during discharge events (Waipaoa River/Poverty Bay; Bever et al., 2011); or non-coherence of river discharge and ocean energy may promote shallow-water deposition (e.g., Rhône and Têt rivers/Gulf of Lions; Drexler and Nittrouer, 2008; Kim et al., 2009). In these types of storm- 
dominated systems, fine-grained material has the opportunity to settle and consolidate between storm events. In contrast, the efficient tidal system of the Elwha inhibits consolidation of muddy sediments because $u_{* c w}$ exceeds the threshold of motion for mud every tidal cycle in the majority of the study area. Given that the time for primary consolidation of muddy sediments is $\sim 1$ day (Winterwerp et al., 1993), this means there is little potential for consolidation of sediments immediately offshore of the river mouth, thus allowing for more efficient and complete dispersal. This characteristic distinguishes the Elwha tidal systems from regions where energy is weaker, more episodic, or sometimes incoherent with river discharge.

Because wave energy on the relict Elwha Delta is typically weaker than tidal energy at $\geq 10 \mathrm{~m}$ depths, and because episodic/storm-driven wave resuspension events are rare, waves play a secondary role in sediment dispersal for this environment at these depths. On daily time scales, tidal currents commonly make the biggest contribution to $u_{* c w}$ (Fig. 2f) and can accomplish most of the transport in the absence of waves. The exceptions are brief periods during slack water and the weakest currents of neap tides, when waves contribute the dominant component of $u_{* c w}$, and wave resuspension may facilitate sediment migration into Freshwater Bay or toward the east side of the delta. However, tidal currents still dominate $u_{* c w}$ during flood currents of neap phases, causing advection and broad dispersal of sediment to the northeast. Thus, on daily time scales, wave-driven transport seems to play a relatively minor role during neap-and especially spring—tidal phases.

On longer time scales, storm-driven wave resuspension events are infrequent and shortlived; note the example from mid-Nov (Fig. 4). In contrast to the tidal-current resuspension events shown in late Nov to Dec 2012 (Fig. 4), this wave event lagged river delivery by several days, and was short-lived relative to the tidal resuspension signals (Fig. 4). Over the time scales 
of the study (Figs. 2 and 3), seasonal variations in both wave energy and current speeds were small, and $u_{* w}$ was generally less than $u_{* c}$ (not shown). Thus, in the absence of wave events, tidal currents alone are sufficient to accomplish broad dispersal of fine-grained sediment outside of Freshwater Bay. In the presence of wave events, tidal transport patterns outside of Freshwater Bay would simply be enhanced and material inside Freshwater Bay may be more easily eroded. In short, whereas fluvial delivery sometimes coincides with marine dispersal energy offshore of systems like the Eel River (coherence versus non-coherence; e.g., Wheatcroft, 2000), fluvial delivery always coincides with marine dispersal energy offshore of the Elwha, a characteristic which precludes accumulation of fine-grained sediment outside of Freshwater Bay (Fig. 7) regardless of the presence or absence of waves.

\subsection{Seabed changes}

In this tidally energetic system, the primary deposit that has formed during heavy fluvial sediment loading at $\geq 10 \mathrm{~m}$ water depth is in Freshwater Bay, west of the river mouth (Fig. 7a, b). This localized mud and sand deposit lies in an embayment where currents are relatively weak (Gelfenbaum et al., 2015). The deposit receives sediment during ebb tides from plume settling, and from flux convergence of sediment advected in the boundary layer. Progressive coarsening both northward and westward from the center of the deposit suggests that tidal currents strengthen with distance from the river mouth, consistent with modeled currents (Gelfenbaum et al, 2009; Gelfenbaum et al., 2015). The BBL instrument data (Fig. 5) suggest that newly delivered sediment is eroded from the deposit during spring tidal phases and infrequent wave events, but remains during neap tidal phases.

In contrast, the seabed at the instrument site and across the relict delta ( $10 \mathrm{~m}$ to $60 \mathrm{~m}$ water depth) is more frequently exposed to stronger tidal currents, and maintained a coarse sand 
and gravel texture from Nov 2011 to Aug 2013 (Fig. 7b) despite fluvial export of 8.2 million tonnes of sediment ( 6.3 million tonnes of suspended load) between Sept 2011 and Sept 2013 (Magirl et al., 2015). Strong currents modeled (Gelfenbaum et al., 2009; Gelfenbaum et al., 2015) and measured (Webster, 2014) across the relict delta suggest that processes similar to those occurring at the instrument site preclude the accumulation of fine-grained sediment on more than $70 \%$ of the total area across the subaqueous delta and Freshwater Bay. This highlights the competency and capacity of tidal currents to disperse fluvial sediment across a range of water depths, especially when compared to a system like the Eel River where a large (8 km x $30 \mathrm{~km})$ flood deposit formed at 50-90 m water depth following the discharge of 34 million tonnes of sediment (Wheatcroft et al., 1997). In that system, tidal currents are generally $10-15 \mathrm{~cm} / \mathrm{s}$ (Geyer et al., 2000), and storm-driven waves and currents are responsible for $>80 \%$ of the boundarylayer transport to the deposit (Ogston and Sternberg, 1999). Reduction of wave energy with depth across the Eel shelf leads to a convergence zone on the mid-shelf, and allows preservation of the fluvial supply history (Sommerfield and Nittrouer, 1999). In the Elwha tidal system, tidal currents - which are conducive to flux convergence and sedimentation in just a small portion of Freshwater Bay-erase the fluvial record across much of the delta.

\subsection{Implications for transport and deposition in other tidally energetic systems}

The Elwha Delta represents an end member for the continuum of tidal- to stormdominated dispersal systems (Fig. 9). In such tidally dominated systems, transport capacity persists before, during, and after fluvial discharge events; net transport occurs in a consistent direction, when integrated over a full tidal cycle; and critical bed stresses may be exceeded often enough to preclude consolidation of mud. When supplied with episodic pulses of sediment (e.g., from a SMR), these dynamics produce small, patchy, sediment deposits in localized zones of 
weak currents or eddies (Fig. 9) where flux convergence promotes deposition. The remaining fine-grained fluvial sediment travels in suspension through the water column and boundary layer, and eventually disperses to deep, distal sinks beyond the limit of tidal resuspension. In both ancient and modern tidal straits, tidal currents have transported sediments as large as sand 10s to 100s of km into deep-water sinks (Reynaud and Dalrymple, 2012; Longhitano, 2013; Harris, 1994). Thus, it is not surprising that sediment discharged from a SMR into a tidally energetic system should escape efficiently.

At the opposite end of the SMR dispersal-system spectrum (Fig. 9), storm events dominate transport, and may be coherent or incoherent with fluvial discharge ("wet” versus “dry” storms; Sommerfield et al., 2007; Draut et al., 2009; Wheatcroft, 2000; Kniskern et al., 2011). During wet storms, river discharge is high, ocean energy is high, and large quantities of fluvial sediment are transported to extensive mid-shelf mud deposits by wind-driven currents and waves (and associated gravity flows) (example: Eel River system, e.g. Wheatcroft et al., 1997; Ogston and Sternberg, 1999). The loss of wave energy at these depths promotes sediment flux convergence and deposition. Unlike tidal energy, such storm energy may last only a few days, and some mud from the fluvial event may remain in shallow nearshore zones (e.g., Crockett and Nittrouer, 2004; Kim et al., 2009; Bever et al., 2011; Grifoll et al., 2014) because of insufficient transport capacity. In the case of dry storms, sediment delivered during a previous discharge event may be eroded and transported by a subsequent storm. In both cases, fluvial sediment may have opportunities to consolidate or become buried before subsequent transport, thus demanding greater transport energy for further dispersal. Also, the storm-driven transport direction (and deposition site) may vary with season (e.g., seasonal monsoon) or the storm itself (cyclonic 
storm; e.g., Sommerfield and Nittrouer, 1999; Ogston et al., 2004; Guillén et al., 2006; Bever et al., 2011).

While the Elwha and Eel systems may be end members in terms of dispersal style, the dominant forcing mechanisms of many other systems lie along a continuum (Fig. 9). In some systems, tidal transport may be important only during spring tidal phases, or the system may have an additional seasonal storm component (which is minimal in the data analyzed here) that may overwhelm the tidal signal. Coastal morphology must also be included as a variable, because embayments or other features allow for variations in tidal-current and wave energy, which drive sediment flux convergence and thus temporary or long-term retention of sediment (Draut et al., 2009; Bever et al., 2011; Bever and Harris, 2014).

Shelf deposits offshore of SMRs in storm-dominated systems yield a wealth of information about flood events, land-use changes, precipitation patterns, and marine processes. Where tidal currents play a major or dominant role, these records may be limited to smaller, more localized zones of weaker currents_or may be completely absent-depending on relative roles of tidal currents, waves, storms, and even coastal morphology. Thus, when considering SMR histories in the modern or long-term stratigraphic record, it is necessary to include tidalcurrent dynamics in interpretations of terrestrial and marine events.

\section{Conclusions}

The Elwha Delta represents a tidal end member of fluvial-marine dispersal systems. In the upper water column, fine-grained sediment settling from the plume may be advected off the delta before reaching the bed. Thus, the sediment would be lost from the study area, and would be unavailable to aggrade seabeds and form flood deposits. In the boundary layer, tidal currents reaching $\sim 50 \mathrm{~cm} / \mathrm{s}$ during neap tides and $>80 \mathrm{~cm} / \mathrm{s}$ during spring tides mobilize mud and sand 
daily at $~ 14-17$ m depth (the primary instrument site). Unequal magnitudes and durations of these flood and ebb currents (i.e., tidal asymmetry) generate net northeastward sediment transport away from the river mouth in the boundary layer. During the study, these processes resulted in non-deposition of sediment across $>70 \%$ of the study area north and northeast of the river mouth, despite the discharge of $\sim 6.3$ million tonnes of suspended sand, silt, and clay over two years (Magirl et al., 2015).

During the same time frame, accumulation of sand and mud (>10 m water depth) was localized to a small region in Freshwater Bay $\left(\sim 2-3 \mathrm{~km}^{2}\right)$ where modeled currents are weakest (Gelfenbaum et al., 2009; Gelfenbaum et al., 2015). Sediment arrives there via ebb tidal currents and direct plume settling. Beyond this deposit at the instrument site, there is a net, northeastward flux of sediment during both spring and neap tides. The flux is smaller during neap tides, however, suggesting greater retention of sediment than during spring tides (especially if coincident with river discharge events), and a possible mechanism for long-term deposit growth and/or maintenance.

The small, isolated Freshwater Bay deposit relative to the large, adjacent nondepositional area exemplifies the localized, patchy deposition expected from tidally dominated systems. Unlike storm-dominated systems, transport energy is perpetually available to disperse fluvial sediment, and is sufficient each day to impede consolidation of sediments. Thus, fluvial sediment pulses are quickly and efficiently partitioned to zones of reduced bed stress, which may lie in nearby embayments or distal portions of the receiving basin, such as the deeper portion of the Strait of Juan de Fuca in this example. And, unlike storm-dominated systems, seasonal energetics are overwhelmed by tidal transport capacities. No matter what the season, fluvial discharge events will always coincide with tidal transport energy, allowing rapid and efficient 
export of fine-grained sediment and the maintenance of coarse substrates offshore of the river mouth.

Because of this efficient dispersal style, the long-term stratigraphic record of terrestrial events may be difficult to locate in this and other tidal systems. When approaching modern or historical sedimentary records of these environments, determining the relative importance of tidal currents versus storm energy is key to interpreting the fate of sediment in the marine environment and resultant history of terrestrial events.

\section{Acknowledgments}

This study was made possible by funding from NSF grant 0960788 and WA Sea Grant project R/ES-65. A host of colleagues and volunteers provided invaluable collaboration, field support, and lab assistance, including: Andy Ritchie from NPS; Steve Rubin from USGS; Ian Miller from WA Sea Grant; the captains and crew of the R/V Barnes; Aaron Fricke, Dan Nowacki, Rip Hale, Katie Boldt, and Kristen Lee Webster from the UW Sediment Dynamics Lab; Brianna Sweeney, Ben Reynolds, Julia Marks, Kevin Simans, and Niall Twomey from the UW School of Oceanography; all of the students from the UW Ocean 492 classes; and all of the volunteers who made the survey cruises successful. The authors also thank two anonymous reviewers for their improvements to the manuscript, and the UW School of Oceanography for providing additional ship time for long-term instrument maintenance and student engagement.

\section{References}

Anderson, F.E., 1968. Seaward terminus of the Vashon continental glacier in the Strait of Juan de Fuca. Marine Geology, 6, 419-438.

Bever, A.J., Harris, C.K., 2014. Storm and fair-weather driven sediment-transport within Poverty Bay, New Zealand, evaluated using coupled numerical models. Continental Shelf Research, 86, 34-51. 
Bever, A.J., McNinch, J.E., Harris, C.K., 2011. Hydrodynamics and sediment-transport in the nearshore of Poverty Bay, New Zealand: Observations of nearshore sediment segregation and oceanic storms. Continental Shelf Research, 31, 507-526.

Bourrin, F., Friend, P.L., Amos, C.L., Manca, E., Ulses, C., Palanques, A., Durrieu de Madron, X., Thompson, C.E.L., 2008. Sediment dispersal from a typical Mediterranean flood: The Têt River, Gulf of Lions. Continental Shelf Research, 28, 1895-1910.

Cannon, G.A., ed., 1978. Circulation in the Strait of Juan de Fuca: Some recent oceanographic observations. NOAA Technical Report ERL 399-PMEL 29, U.S. Department of Commerce, Boulder, Colorado.

Cartwright, G.M., Friedrichs, C.T., Smith, S.J., 2013. A test of the ADV-based Reynolds flux method for in situ estimation of sediment settling velocity in a muddy estuary. GeoMarine Letters, 33, 477-484.

Crockett, J.S., Nittrouer, C.A., 2004. The sandy inner shelf as a repository for muddy sediment: an example from northern California. Continental Shelf Research, 24, 55-73.

Curran, C.A., Konrad, C.P., Higgins, J.L., Bryant, M.K., 2009. Estimates of sediment load prior to dam removal in the Elwha River, Clallam County, U.S. Geological Survey Scientific Investigations Report 2009-5221.

Curran, C.A., Magirl, C.S., Duda, J.J., 2014. Suspended-sediment concentration during dam decommissioning in the Elwha River, Washington: U.S. Geological Survey Data Set, http://wa.water.usgs.gov/pubs/misc/elwha/ssc/, doi:10.5066/F7M043DB.

Deines, K.L., 1999. Backscatter estimation using broadband acoustic Doppler current profilers. Proceedings, Sixth Working Conference on Current Measurement, Sand Diego, CA, IEEE, 249-253.

Downing, J., 1983. The coast of Puget Sound: Its processes and development. Puget Sound Books, Washington Sea Grant, University of Washington Press, Seattle.

Downing, J., 2006. Twenty-five years with OBS sensors: The good, the bad, and the ugly. Continental Shelf Research, 26, 2299-2318.

Draut, A.E., Bothner, M.H., Reynolds, R.L., Field, M.E., Cochran, S.A., Logan, J.B., Storlazzi, C.D., Berg, C.J., 2009. Supply and dispersal of seasonal flood deposits in Hanalei Bay, Kaua'i, HI, USA: Implications for coral-reef ecosystems. Geological Society of America Bulletin, 121(3-4), 574-585.

Drexler, T., Nittrouer, C., 2008. Stratigraphic signatures due to flood deposition near the Rhone River: Gulf of Lions, northwest Mediterranean Sea. Continental Shelf Research, 28(15), 1877-1894.

Dyer, K.R., 1994. Estuarine sediment transport and deposition, in Pye, K., ed. Sediment Transport and Depositional Processes. Blackwell Scientific Publications, Oxford.

Fain, A.M.V., Ogston, A.S., Sternberg, R.W., 2007. Sediment transport event analysis on the western Adriatic continental shelf. Continental Shelf Research, 27, 431-451.

Fissel, D.B., and Huggett, W.S., 1976. Observations of currents, bottom pressures and densities through a cross-section of Juan de Fuca Strait. Pacific Marine Science Report 76-6, Institute of Ocean Sciences, Patricia Bay, Victoria.

Folk, R.L., 1954. The distinction between grain size and mineral composition in sedimentaryrock nomenclature. The Journal of Geology, 62(4), 344-359.

Fugate, D.C., Friedrichs, C.T., 2002. Determining concentration and fall velocity of estuarine particle populations using ADV, OBS and LISST. Continental Shelf Research, 22, 18671886. 
Galster, R.W., Schwartz, M.L., 1990. Ediz Hook-A case history of coastal erosion and mitigation. Journal of Coastal Research, 6, 103-113.

Gelfenbaum, G., Stevens, A.W., Elias, E., Warrick, J.A., 2009. Modeling sediment transport and delta morphology on the dammed Elwha River, Washington State, USA. Proceedings, Coastal Dynamics 2009, Paper No. 109.

Gelfenbaum, G., Stevens, A.W., Miller, I., Warrick, J.A., Ogston, A.S., Eidam, E., 2015. Largescale dam removal on the Elwha River, Washington, USA: Coastal geomorphic change. Geomorphology, 246, 649-668.

Geyer, W.R., Hill, P., Milligan, T., Traykovski, P., 2000. The structure of the Eel River plume during floods. Continental Shelf Research, 20, 2067-2093.

Grifoll, M., Gracia, V., Aretxabaleta, A., Guillén, J., Espino, M., Warner, J.C., 2014. Formation of fine sediment deposits from a flash flood river in the Mediterranean Sea. Journal of Geophysical Research: Oceans, 119, 5837-5853.

Guillén, J., Bourrin, F., Palanques, A., Durrieu de Madron, X., Puig, P., Buscail, R., 2006. Sediment dynamics during wet and dry storms events on the Têt inner shelf (SW Gulf of Lions). Marine Geology 234, 129-142.

Harris, C.K., Sherwood, C.R., Signell, R.P., Bever, A.J., Warner, J.C., 2008. Sediment dispersal in the northwestern Adriatic Sea. Journal of Geophysical Research: Oceans. 113, 1-18.

Harris, P.T., 1994. Comparison of tropical, carbonate and temperate, siliclastic tidally dominated sedimentary deposits: Examples from the Australian continental shelf. Australian Journal of Earth Sciences, 41(3), 241-254.

Hill, P.S., Milligan, T.G., Geyer, W.R., 2000. Controls on effective settling velocity of suspended sediment in the Eel River flood plume. Continental Shelf Research, 20, 20952111.

Holbrook, J.R., Muench, R.D., Kachel, D.G., Wright, C., 1980. Recent oceanographic observations in the eastern basin. National Oceanic and Atmospheric Administration, Pacific Marine Environmental Laboratory, Technical Report 33, Seattle.

Inman, D.L., 1949. Sorting of sediments in the light of fluid mechanics. Journal of Sedimentary Petrology, 19, 51-70.

Kim, J.-H., Buscail, R., Bourrin, F., Palanques, A., Sinninghe Damsté, J.S., Bonnin, J., Schouten, S., 2009. Transport and depositional process of soil organic matter during wet and dry storms on the Têt inner shelf (NW Mediterranean). Palaeogeography, Palaeoclimatology, Palaeoecology, 273, 228-238.

Kniskern, T.A., Warrick, J.A., Farnsworth, K.L., Wheatcroft, R.A., Goñi, M.A., 2011. Coherence of river and ocean conditions along the US West Coast during storms. Continental Shelf Research, 31, 789-805.

Konrad, C.P., 2009. Simulating the recovery of suspended sediment transport and river-bed stability in response to dam removal on the Elwha River, Washington. Ecological Engineering, 35, 1104-1115.

Labrecque, A.J.M., Thomson, R.E., Stacey, M.W., Buckley, J.R., 2010. Residual Currents in Juan de Fuca Strait. Atmosphere-Ocean, 32(2), 375-394.

Longhitano, S.G., 2013. A facies-based depositional model for ancient and modern, tectonicallyconfined tidal straits. Terra Nova, 25, 446-452.

Madsen, O.S., 1994. Spectral wave-current bottom boundary layer flows. In: Coastal Engineering 1994: Proceedings, 24th International Conference, Coastal Engineering Research Council. American Society of Civil Engineers, Kobe, Japan, pp. 384-398. 
Magirl, C.S., Hilldale, R.C., Curran, C.A., Duda, J.J., Straub, T.D., Domanski, M., Foreman, J.R., 2015. Large-scale dam removal on the Elwha River, Washington, USA: Fluvial sediment load. Geomorphology, 246, 669-686.

Miller, M.C., McCave, I.N., Komar, P.D., 1977. Threshold of sediment motion under unidirectional currents. Sedimentology, 24, 507-527.

Milliman, J.D., Syvitski, J.P.M., 1992. Geomorphic/Tectonic control of sediment discharge to the ocean: The importance of small mountainous rivers. The Journal of Geology, 100, 525-544.

Mosher, D.C., Hewitt, A.T., 2004. Late Quaternary deglaciation and sea-level history of eastern Juan de Fuca Strait, Cascadia. Quaternary International, 121, 23-39.

Ogston, A.S., Cacchione, D.A., Sternberg, R.W., Kineke, G.C., 2000. Observations of storm and river flood-driven sediment transport on the northern California continental shelf. Continental Shelf Research, 20(16), 2141-2162.

Ogston, A.S., Drexler, T.M., Puig, P., 2008. Sediment delivery, resuspension, and transport in two contrasting canyon environments in the southwest Gulf of Lions. Continental Shelf Research, 28(15), 2000-2016.

Ogston, A.S., Guerra, J.V., Sternberg, R.W., 2004. Interannual variability of nearbed sediment flux on the Eel River shelf, northern California. Continental Shelf Research, 24(1), 117136.

Ogston, A.S., Sternberg, R.W., 1999. Sediment-transport events on the northern California continental shelf. Marine Geology, 154, 69-82.

Philips, E.L., Donaldson, W.R., 1972. Washington climate for Clallam, Grays Harbor, Jefferson, Pacific, and Wahkiakum counties. Cooperative Extension Service Publication EM 3708. Washington State University, Pullman, Washington.

Postma, H., 1961. Transport and accumulation of suspended matter in the Dutch Wadden Sea. Netherlands Journal of Sea Research, 1(1/2), 148-190.

Reading, H.G., 2009. Sedimentary environments: processes, facies, and stratigraphy. John Wiley \& Sons, Chichester.

Reynaud, J.-Y., Dalrymple, R.W., 2012. Shallow-marine tidal deposits, in Davis, R.A. Jr., Dalrymple, R.W., eds., Principles of Tidal Sedimentology, Springer, New York.

Rigg, G.B., 1913. Is salinity a factor in the distribution of Nereocystis Luetkeana? Bulletin of the Torrey Botanical Club, 40(5), 237-242.

Rigg, G.B., 1915. The kelp beds of Puget Sound, in Cameron, F.K., Potash from kelp. United States Department of Agriculture, Bureau of Soils, report no. 100, Washington government printing office.

Shaffer, J.A., Crain, P., Winter, B., McHenry, M.L., Lear, C., Randle, T.J., 2008. Nearshore restoration of the Elwha River through removal of the Elwha and Glines Canyon dams: An overview. Northwest Science, 82 (Special Issue), 48-58.

Sommerfield, C.K., Nittrouer, C.A., 1999. Modern accumulation rates and a sediment budget for the Eel shelf: a flood-dominated depositional environment. Marine Geology, 154, 227241.

Sommerfield, C.K., Ogston, A.S., Mullenbach, B.L., Drake, D.E., Alexander, C.R., Nittrouer, C.A., Borgeld, J.C., Wheatcroft, R.A., Leithold, E.L., 2007. Oceanic dispersal and accumulation of river sediment, in Nittrouer, C.A., Austin, J.A., Field, M.E., Kravitz, J.H., Syvitski, J.P.M., Wiberg, P.L. (Eds.), Continental Margin Sedimentation: From 
Sediment Transport to Sequence Stratigraphy, IAP Special Publication, 37, Blackwell Publishing, Oxford (2007), pp. 157-212.

Soulsby, R.L., 1997. Dynamics of marine sands: A manual for practical applications. Thomas Telford Services Limited, London.

Sternberg, R.W., 1968. Friction factors in tidal channels with differing bed roughness. Marine Geology, 6, 243-260.

Swift, D.J.P., Han, G., Vincent, C.E., 1986. Fluid processes and sea-floor response on a modern storm-dominated shelf: Middle Atlantic Shelf of North America in Knight, R.J., McLean, J.R. (Eds.), Shelf sands and sandstones. Canadian Society of Petroleum Geologists, Memoir II, 99-119.

Thomson, R.E., Mihály, S.F., Kulikov, E.A., 2007. Estuarine versus transient flow regimes in Juan de Fuca Strait. Journal of Geophysical Research, 112, C09022, 1-25.

Ulses, C., Estournel, C., Durrieu de Madron, X., Palanques, A., 2008. Suspended sediment transport in the Gulf of Lions (NW Mediterranean): Impact of extreme storms and floods. Continental Shelf Research, 28, 2048-2070.

USGS (United States Geological Survey), 2015. National Water Information System: U.S. Geological Survey database, accessed December 8, 2015, at http://waterdata.usgs.gov/wa/nwis.

Walker, R.G., 1984. Facies models. Geoscience Canada reprint series, no. 1, Geological Association of Canada Publications, Business and Economic Service, Toronto.

Warrick, J.A., Bountry, J.A., East, A.E., Magirl, C.S., Randle, T.J., Gelfenbaum, G., Ritchie, A.C., Pess, G.R., Leung, V., Duda, J.J., 2015. Large-scale dam removal on the Elwha River, Washington, USA: Source-to-sink sediment budget and synthesis. Geomorphology, 246, 729-750.

Warrick, J.A., Cochrane, G.R., Sagy, Y., Gelfenbaum, G., 2008. Nearshore substrate and morphology offshore of the Elwha River, Washington. Northwest Science, 82 (Special Issue), 153-163.

Warrick, J.A., George, D.A., Gelfenbaum, G., Ruggiero, P., Kaminsky, G.M., Beirne, M., 2009. Beach morphology and change along the mixed grain-size delta of the dammed Elwha River, Washington. Geomorphology, 111(3-4), 136-148.

Warrick, J.A., Stevens, A.W., 2011. A buoyant plume adjacent to a headland-Observations of the Elwha River plume. Continental Shelf Research, 31, 85-97.

Webster, K.L., 2014. Sediment dispersal and accumulation in an insular sea: deltas of Puget Sound. PhD dissertation, University of Washington.

Wheatcroft, R.A., 2000. Oceanic flood sedimentation: a new perspective. Continental Shelf Research, 20, 2059-2066.

Wheatcroft, R.A., Sommerfield, C.K., Drake, D.E., Borgeld, J.C., Nittrouer, C.A., 1997. Rapid and widespread dispersal of flood sediment on the northern California margin. Geology, 25, 163-166.

Winterwerp, J.C., Cornelisse, J.M., Kuijper, C., 1993. A laboratory study on the behavior of mud from the Western Scheldt under tidal conditions, in Mehta, ed., Coastal and Estuarine Studies: Nearshore and Estuarine Cohesive Sediment Transport, American Geophysical Union, Washington, DC.

Wright, L. D., Kim, S.C., Friedrichs, C.T., 1999. Across-shelf variations in bed roughness, bed stress and sediment suspension on the northern California shelf. Marine Geology, 154 (14), 99-115. 
Figure 1. Study area, composed of (west to east): Freshwater Bay; the relict, subaqueous Elwha Delta; and Ediz Hook. Instrumented tripods were located northwest of the river mouth in 15-25 $\mathrm{m}$ water depth. Seabed grab samples, water samples, and CTD transects were collected primarily at sites 10-60 m deep within $3 \mathrm{~km}$ of the river mouth. Bathymetric contour intervals are $5 \mathrm{~m}$ (courtesy of UW School of Oceanography, www.ocean.washington.edu/data/pugetsound).

Figure 2. Hydrodynamics and suspended-sediment data from the river, (a) and (b), and boundary layer at the primary instrument site, (c)-(g), during the 20-month study period. (a) Elwha River discharge and SSC (data courtesy USGS); (b) Elwha River cumulative fluvial sediment load (=0 at the start of each interval; data courtesy USGS); (c) salinity and temperature in the boundary layer; (d) significant wave heights; (e) tidal currents and wave-orbital velocities; (f) $\mathrm{u}_{\mathrm{c}}{ }_{\mathrm{c}}, \mathrm{u}_{\mathrm{c}}$, and $\mathrm{u}_{\mathrm{w}}$; (g) SSC. Data gaps occurred in Apr 2012, Jun-Oct 2012, and Jan-Apr 2013 during periods of instrument maintenance and/or malfunction.

Figure 3. Hydrography and hydrodynamics by season. (a) Classification of seasons based on mean river hydrograph (seasons were loosely defined based on long-term river discharge greater or less than $\sim 43 \mathrm{~m}^{3} / \mathrm{s}$ ). (b) Percent occurrence of current speeds, wave orbital velocities, and total (wave-current) shear velocity for observed data within calendar year 2012, by season.

Figure 4. Comparison of wave and tidal sediment resuspension over a two-month time period. (a) Elwha River discharge and turbidity (data courtesy USGS); (b) current speeds, 50 cmab; (c) SSC, 50 cmab; (d) wave-orbital velocities, $50 \mathrm{cmab}$. All fluvial delivery events were accompanied by immediate SSC increases in the boundary layer on tidal time scales. A few anomalous wave events (e.g., mid-Nov) caused boundary-layer resuspension not coincident with fluvial delivery.

Figure 5. Diurnal-scale time-series data illustrating typical resuspension, advection and settling patterns during spring and neap tidal currents. Panels show (top to bottom) corrected acoustic backscatter, current vectors, current and wave-orbital velocities, suspended-sediment concentrations, combined wave-current shear velocities, and mean settling velocities of the total particle population. During both spring and neap tides, vertical and horizontal concentration gradients form throughout the water column, and SSC peaks during maximum and minimum current flow. Shear velocities and mean particle sizes are smaller during neap tides.

Figure 6. Sediment-trap grain-size distributions. Distributions of disaggregated particle sizes were dominated by silt at both instrument sites in all seasons.

Figure 7. Seabed grain-size changes from samples collected in (a) Nov 2011 and Apr 2012, 2 to 7 months after the start of dam removal and (b) Apr 2013 and Aug 2013, 19 to 23 months after the start of dam removal. Early in the project (a), substrate sizes were dominated by pre-existing gravel across most of the delta except for a sandy patch in Freshwater Bay. By 2013 (b), mud and sand were found in Freshwater Bay. Black points denote failed sampling attempts or small samples (likely indicative of a coarse substrate). Bathymetric contour intervals are $5 \mathrm{~m}$ (courtesy of UW School of Oceanography, www.ocean.washington.edu/data/pugetsound). 
Figure 8. Conceptual patterns of sediment dispersal within the boundary layer during (a) spring tides and (b) neap tides. During spring tides, transport capacity (magnitude, duration, particle size) is much greater on flood tides than ebb tides, implying net northeastward migration of sediment. Direct plume settling may facilitate sediment accumulation in Freshwater Bay during ebb tides, but much of this material is likely dispersed during flood tides. During neap tides, sediment transport capacity is reduced (and the flood-ebb inequality is smaller); sediment is more likely to accumulate in Freshwater Bay. (FWB = Freshwater Bay.)

Figure 9. Simplified conceptual model of continuum between storm- and tide-dominated dispersal systems. In storm-dominated systems, episodic wind-driven currents and waves partition fine-grained sediment to mid-shelf mud belts. In tide-dominated systems, strong, persistent tidal currents broadly disperse much of the fine-grained sediment, leaving patchy deposits. Along the continuum, the role of fair-weather waves and episodic storm energy becomes more important, as the influence of tidal currents diminishes. The style of deposits in these systems likely depends on the relative importance of these forcing mechanisms, as well as the grain size of sediment supplied and shoreline complexity. 
Figure 1

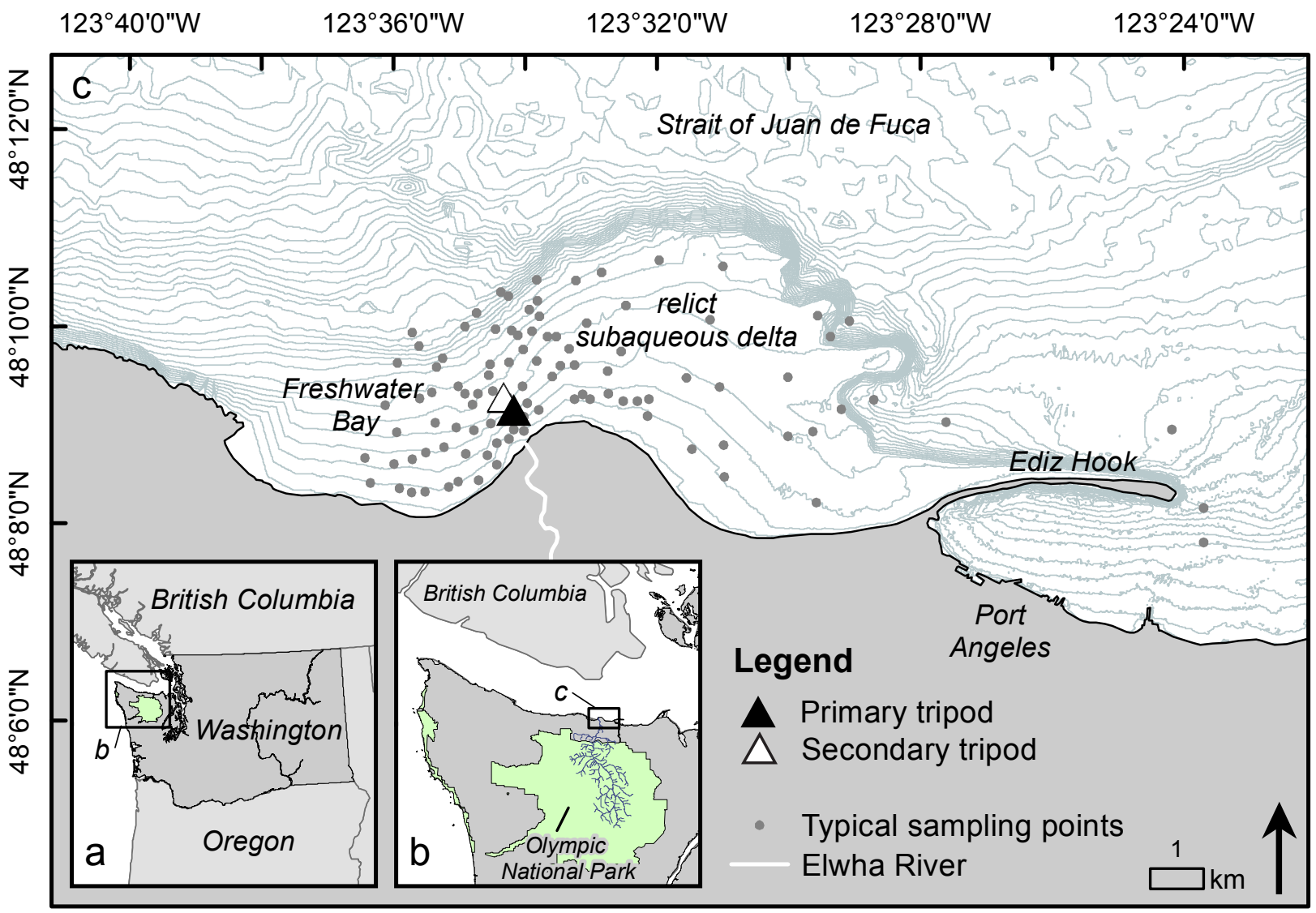




\section{Figure 2}

$6 \nabla N 0$

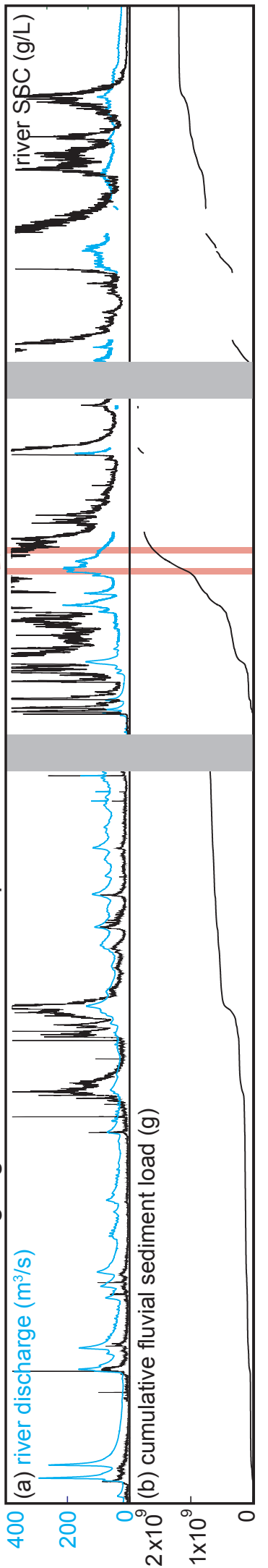

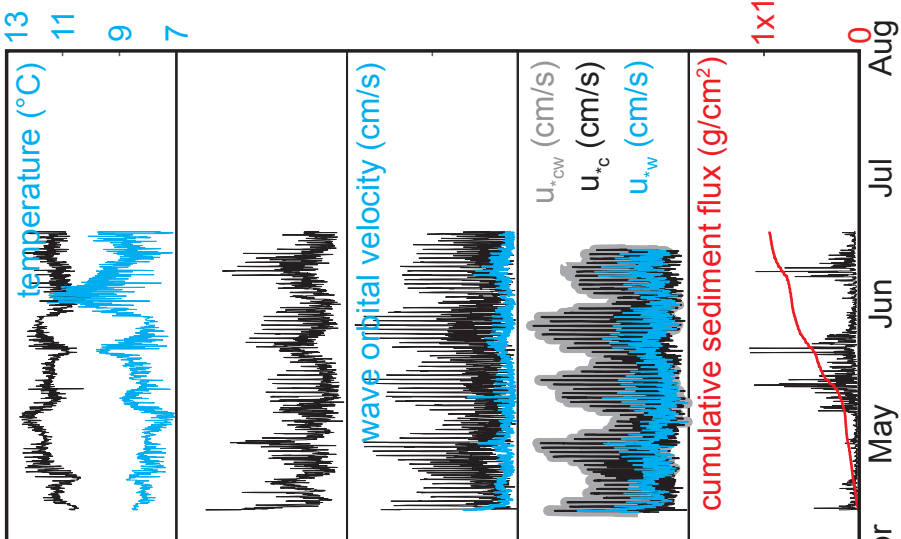

훙

क
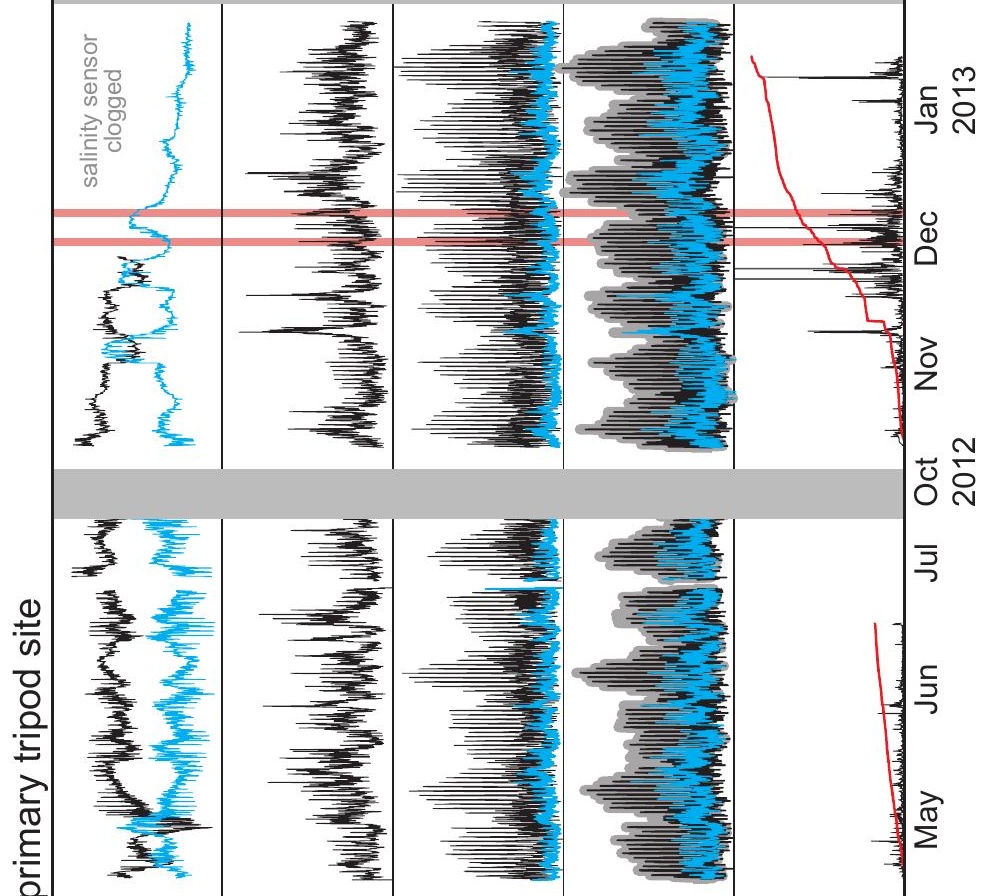

¿ั $\stackrel{N}{\stackrel{N}{2}}$

इ

독

$\stackrel{\sqrt{6}}{\Sigma}$

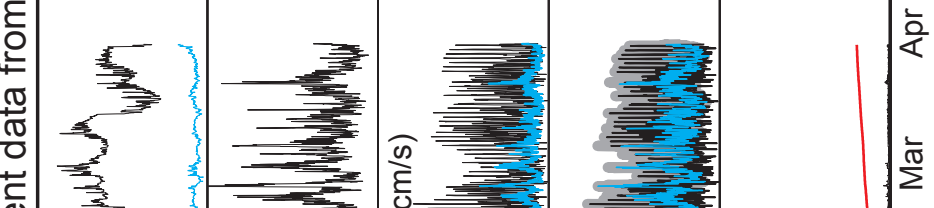

衣争

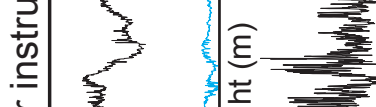

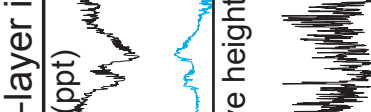

坖就

号管

이, 흐, क्ञ

ô

0 늘

¿

을

$\Sigma$

원

$\stackrel{\frac{N}{\sigma}}{\frac{N}{⿱ 乛}}$

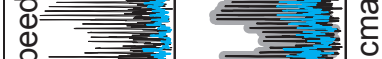

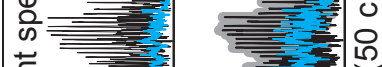

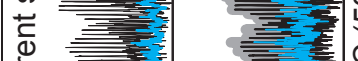

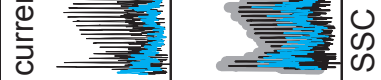

|

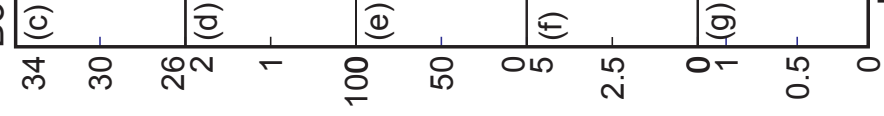




\section{Figure 4}

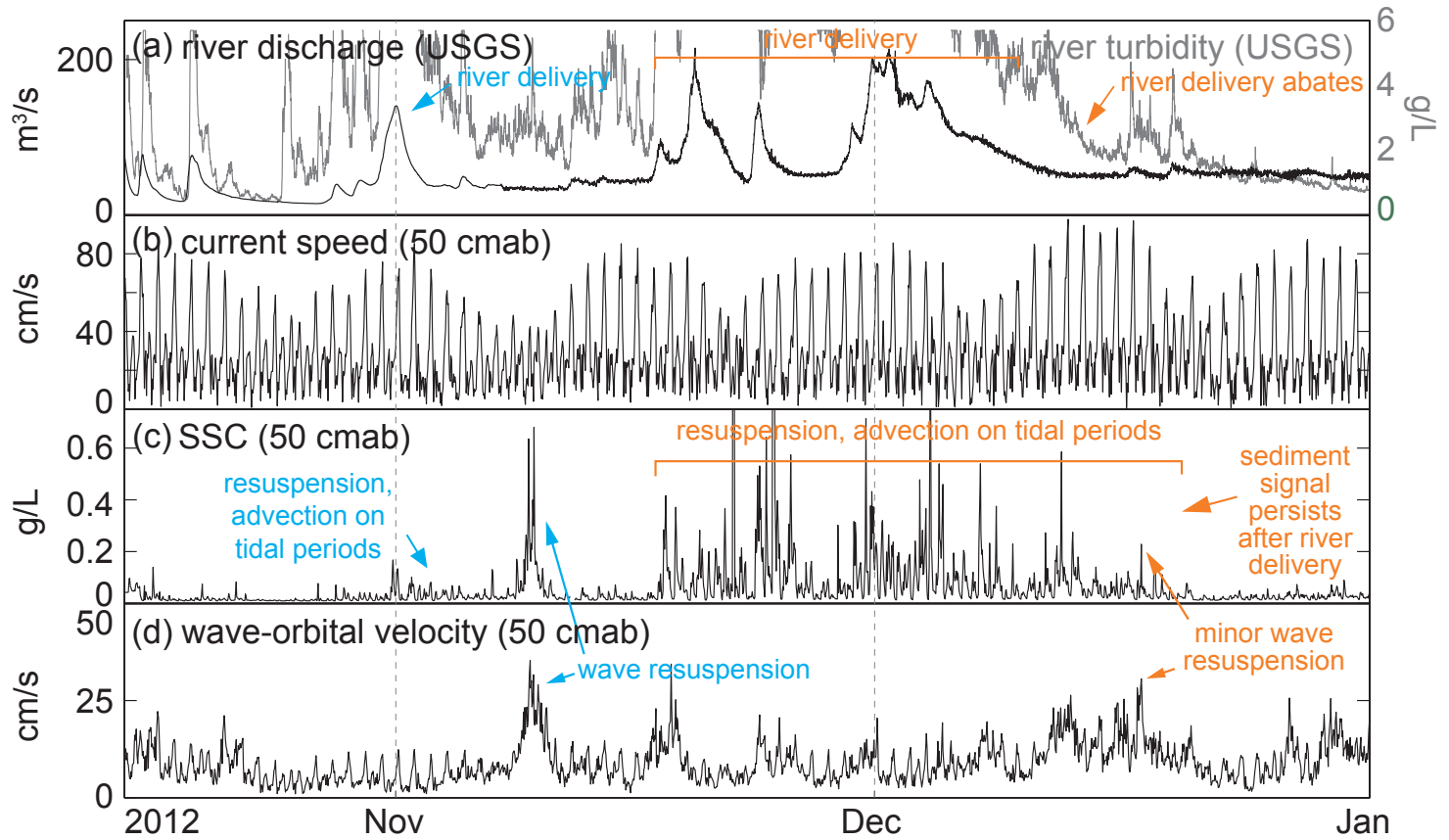




\section{Figure 5}
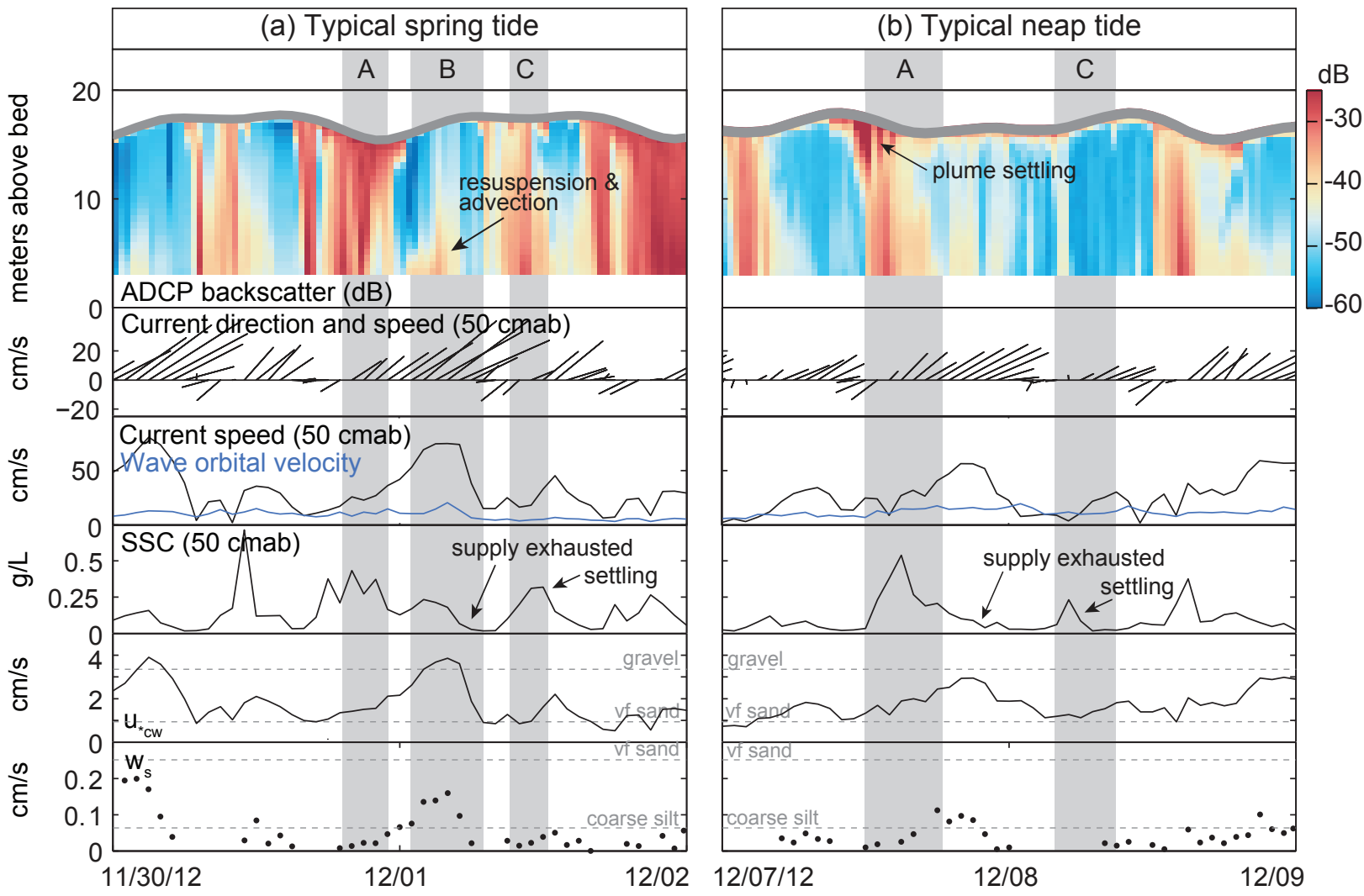
Figure 6

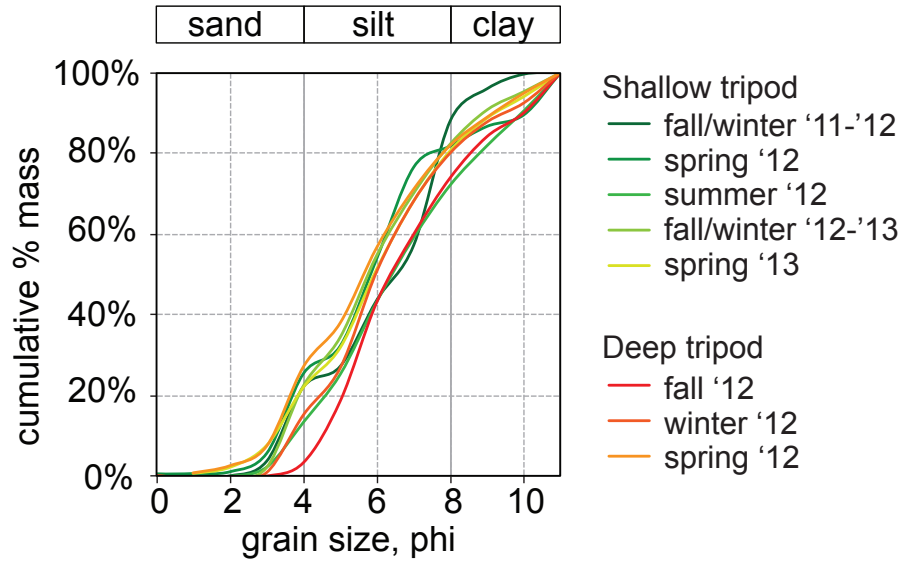




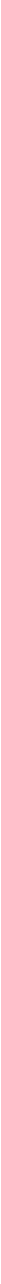 \\ Figure 7}


Table 1. Instruments deployed on the primary tripod, with elevations and sampling schemes.

\begin{tabular}{lcc}
\hline Instrument & $\begin{array}{c}\text { Elevation above } \\
\text { bed (cmab, or } \\
\text { cm above bed) }\end{array}$ & Sampling scheme \\
\hline Primary tripod & & \\
$\quad$ Acoustic Doppler current profiler (ADCP), up-looking 600 kHz & 200 & $60 \mathrm{~s} / 30 \mathrm{~min} @ 2 \mathrm{~Hz}$ \\
$\quad$ High-resolution acoustic Doppler current profiler (hrADCP), & & \\
$\quad$ down-looking 2MHz & $50^{*}$ & $360 \mathrm{~s} / 60 \mathrm{~min} @ 2-16 \mathrm{~Hz}$ \\
$\quad$ Acoustic Doppler velocimeter (ADV) & 48 & $360 \mathrm{~s} / 60 \mathrm{~min} @ 2-16 \mathrm{~Hz}$ \\
$\quad$ Conductivity / temperature / depth sensor (CTD) & $15,30,49,101$, & (see ADV scheme) \\
$\quad$ Optical backscatter sensor (OBS) & 192 & \\
$\quad \begin{array}{l}111 \pm 5 \\
\text { Sediment tube trap }\end{array}$ & \\
Secondary tripod - Same instruments as primary except for hrADCP, 30 cmab OBS, and $192 \mathrm{cmab}$ OBS \\
\hline
\end{tabular}

* Elevation to sample volume 